\title{
Platelet profile in patients with gestational diabetes: a retrospective study
}

\section{Gestasyonel diabetik hastalarda trombosit profili: retrospektif değerlendirme}

Muhammet Erdal Sak ${ }^{1}$, Hatice Ender Soydinç ${ }^{1}$, Ali Özler', Mehmet Sıddık Evsen ${ }^{1}$, Abdülkadir Turgut ${ }^{1}$, Sibel Sak², Talip Gül

'Dicle University, School of Medicine, Department of Obstetrics And Gynecology, Diyarbakur, Turkey

${ }^{2}$ Diyarbakır Maternity And Children Hospital, Department of Obstetrics And Gynecology, Diyarbakır, Turkey

\section{Abstract}

Objective: To assess and compare alterations in the morphology and function of platelets occurring in gestational diabetes and healthy pregnancies.

Material and Methods: A retrospective study was performed of 77 pregnant women: 42 cases with gestational diabetes and 35 healthy controls. The two groups were compared in terms of demographics and platelet parameters derived from complete blood counts.

Results: The mean platelet volume $(p=0.001)$ and HbAlc $(p<0.001)$ were significantly increased in the patients with gestational diabetes. The mean platelet volume was well correlated with the platelet distribution width ( $\mathrm{rs}=0.404, p<0.001)$ and the platelet count $(\mathrm{rs}=0.355$, $p=0.002$ )

Conclusion: The mean platelet volume and other platelet parameters may significantly aid the identification of diabetic pregnants at risk for vascular complications. The role and possible clinical relevance of these changes during diabetic pregnancy need to be investigated in further studies. (J Turkish-German Gynecol Assoc 2012; 13: 223-6)

Key words: Pregnancy, diabetes, gestational diabetes, platelet, mean platelet volume

Received: 26 July, 2012

Accepted: 04 October, 2012

\section{Ozet}

Amaç: Gestasyonel diabet ve sağlıklı gebelerde trombosit morfolojisi ve fonksiyonlarını değerlendirmek ve karşılaştırmak amaçlanmıştır.

Gereç ve Yöntemler: Kırk iki gestasyonel diabet, 35 sağlıklı kontrol olarak toplam 77 gebe hasta retrospektif olarak değerlendirildi. İki grup demografik veriler ve tam kan sayımından elde edilen trombosit parametreleri açısından karşılaştırıldı.

Bulgular: Gestasyonel diabet olgularında; ortalama trombosit hacmi $(p=0.001)$ ve HbAlc $(p<0.001)$ anlamlı olarak artmış saptandı. Ortalama trombosit hacmi , trombosit dağılım genişliği ( $\mathrm{rs}=0.404, p<0.001)$ ve trombosit sayımı ( $r s=0.355, p=0.002)$ ile ilişkili bulundu.

Sonuç: Ortalama trombosit hacmi ve diğer trombosit parametreleri vasküler komplikasyonlar açısından risk altında olan diyabetik gebelerin belirlenmesinde önemli ölçüde yardımcı olabilir. Gestasyonel diyabetik gebelerdeki bu değişikliklerin rolü ve olası klinik ilişkisi için ileri çalışmalar yapılmalıdır.

(J Turkish-German Gynecol Assoc 2012; 13: 223-6)

Anahtar kelimeler: Gebelik, diabet, gestasyonel diabet, trombosit, ortalama trombosit hacmi

Geliş Tarihi: 26 Temmuz 2012

Kabul Tarihi: 04 Ekim 2012

\section{Introduction}

Altered platelet morphology and function have been reported in patients with diabetes mellitus (1). These changes may be associated with increased risk of vascular disease and venous thromboembolism (1-3). Although normal pregnancy may result in the activation of primary hemostasis and coagulation, these issues have not been widely investigated in gestational diabetes (GD).

Patients with diabetes mellitus show altered platelet function, including decreased nitric oxide synthase activity and increased peroxynitrite production (4-6). Platelet volumes are direct indicators of increased platelet synthesis (4). In normal pregnancies, a small increase in platelet aggregation occurs. This increase is compensated for by increased platelet synthesis and, consequently, in an increased mean platelet volume (MPV) $(3,7)$. The MPV is an indicator of platelet activation. In a normal pregnancy, changes in platelet volumes may be more sensitive than platelet numbers as a measure of altered platelet function (8). It is also increased in acute myocardial infarction, acute ischemic stroke, pre-eclampsia and renal artery stenosis (9). Importantly, an elevated MPV predicts a poor outcome following myocardial infarction, restenosis following coronary angioplasty, and the development of pre-eclampsia $(5,8,9)$.

The present study was designed to compare and assess the demographic and laboratory findings in healthy pregnant women and GD patients. As far as we know, such a comparative study has not been reported previously in the literature.

\section{Material and Methods}

A retrospective study was performed in the obstetrics and gynecology department of a tertiary care center on the medical records of 77 pregnants (42 GD cases, 35 controls) diag- 
nosed between February 2010 and February 2012. After obtaining the approval of the Institutional Review Board, patients' files were reviewed to collect relevant demographic, clinical, and laboratory data. Women with systemic diseases (hypertension, collagen tissue disease, heart disease, renal disease, hepatic disease) or a poor obstetric history requiring medication during gestation (recurrent pregnancy loss, previous occurrence of pre-eclampsia, preterm labor, intrauterine growth retardation, or intrauterine demise) were excluded from the study.

All women with GD had normal medical histories before pregnancy. The patients were screened with a 50-gram (g), 1-hour (h) glucose tolerance test between 24 and 28 weeks of pregnancy. In accordance with the recommendations of the American Diabetes Association, patients with a plasma glucose threshold value of $140 \mathrm{mg} / \mathrm{dl}$ one hour after glucose load intake under nonfasting conditions were included in the study. When the plasma glucose level reached $\geq 140 \mathrm{mg} / \mathrm{dl}$ following the 50-g oral glucose loading test, which was administered at 24-28 gestational weeks, a 100-g, 3-h oral glucose tolerance test was administered. The patients who had high values from both tests were considered to have GD. The patients were instructed to monitor their blood glucose levels. The patients were given information about nutrition and advised to perform physical activity for $30 \mathrm{~min} /$ day. Patients who had not achieved target levels were treated with human regular and neutral protamine hagedorn (NPH) insulin preparations used in multiple injection regimens. The body mass index and $\mathrm{HbAlc}$ of the patients were measured at the time of diagnosis. A fasting peripheral venous blood sample was obtained from all the participants in their last trimester (32-36 weeks). To avoid the platelet swelling induced by ethylene diamine tetra acetate (EDTA), blood samples were analyzed within half an hour of collection. An automated blood counter (CELL-DYN 3500, Abbott Diagnostics, Santa Clara, CA, USA) was used to measure complete blood count (CBC) parameters. Positivity for ketone bodies in the urine was investigated using the dipstick method (Siemens Multistix 10SG, Germany).

Statistical analysis was carried out using the SPSS 11.0 computer program (SPSS Inc, Chicago, IL, USA). Nonparametric tests were chosen for comparison due to the relatively small sample size. The Mann-Whitney test, student's $t$ test, and Spearman correlation analysis were utilized when appropriate. $p<0.05$ was regarded as significant.

\section{Results}

Analysis of the data showed that the body mass index and the number of parities were increased in parallel with the advancement of age ( $r s=0.344, \mathrm{p}=0.002$; and $\mathrm{rs}=0.515, \mathrm{p}<0.001$ respectively). The MPV was well correlated with the platelet distribution width ( $\mathrm{rs}=0.404, \mathrm{p}<0.001)$ and the platelet count ( $r s=0.355, \mathrm{p}=0.002$ ).

Comparison of the two groups revealed that the MPV $(p=0.001)$ and the HbAlc $(\mathrm{p}<0.001)$ were increased in GD (Table 1, Figure 1).

\section{Discussion}

Altered platelet morphology and function have been reported in patients with diabetes $(6,8,9)$. Patients with diabetes have increased platelet activation compared to nondiabetic subjects (8-10). Platelet hyperactivity was accompanied by increased synthesis of thromboxane and/or decreased prostacycline production. MPV is a marker of platelet function and activation (11). Larger platelets are both more reactive and aggregable. They contain denser granules, secrete more serotonin and b-thromboglobulin, and produce more thromboxane A2 than smaller platelets. This points to a relationship between platelet function and micro- and macrovascular complications of diabetes mellitus (DM) (8-12).

Recently, an increase in MPV in the late phase of myocardial infarction has been shown to be an independent predictor for

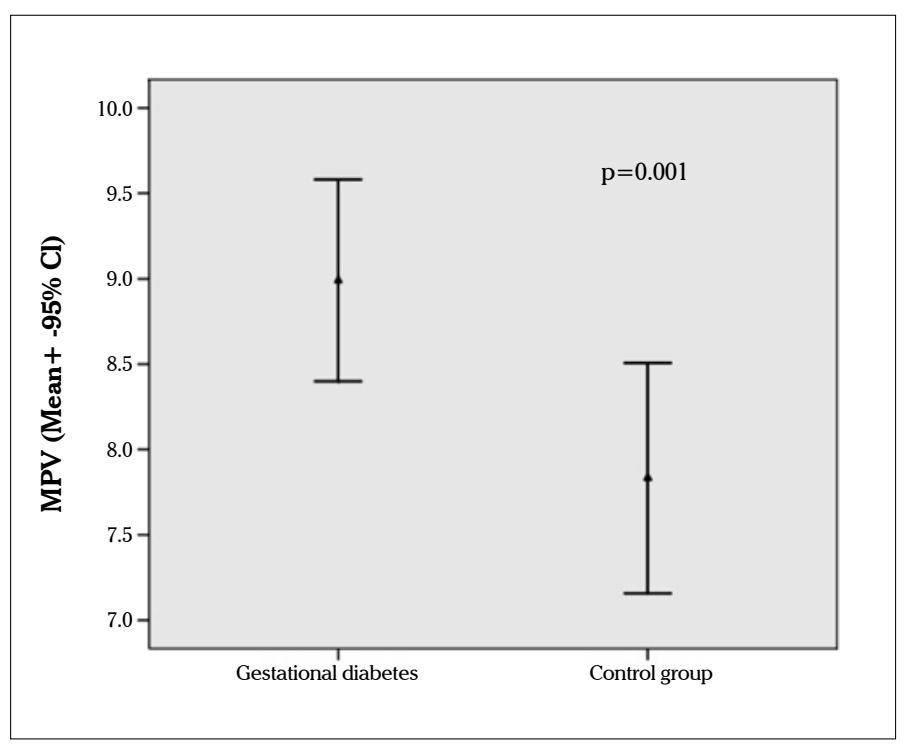

Figure 1. Comparison of MPV values in gestational diabetes and controls

Table 1. Demographic, clinical, and laboratory properties of the study and control groups (mean \pm standard deviation)

\begin{tabular}{|l|c|c|c|}
\hline & Diabetes & Control & p Value \\
\hline Age & $31.2 \pm 4.1$ & $30.7 \pm 3.8$ & 0.224 \\
\hline Parity & $1.8 \pm 1.6$ & $1.6 \pm 1.5$ & 0.634 \\
\hline BMI & $28.6 \pm 2.4$ & $27.5 \pm 3.6$ & $0.048^{*}$ \\
\hline Leukocyte count & $9.9 \pm 2.2$ & $10.2 \pm 2.8$ & 0.701 \\
\hline HbAlc & $5.7 \pm 1.0$ & $4.7 \pm 0.6$ & $<0.001^{*}$ \\
\hline Hct & $34.7 \pm 3.2$ & $33.5 \pm 2.8$ & $0.024^{*}$ \\
\hline Platelet count & $250.4 \pm 64.4$ & $256.8 \pm 63.8$ & 0.567 \\
\hline MPV & $8.9 \pm 1.9$ & $7.8 \pm 2.0$ & $0.001 *$ \\
\hline PDW & $18.2 \pm 1.2$ & $18.1 \pm 1.4$ & 0.566 \\
\hline $\begin{array}{l}\text { (BMI: body-mass index, HbAlc: glycosylated hemoglobin, Hct: hemato- } \\
\text { crit, MPV: mean platelet volume, PDW: platelet distribution width) } \\
\text { * denotes statistical significance }\end{array}$ \\
\hline
\end{tabular}


recurrent myocardial infarction $(5,7)$. Platelet hyperactivity in DM may be a contributor to severe and profound vasculopathies associated with this disorder $(6,8)$. Increased platelet aggregation has been demonstrated in $\mathrm{DM}$, and this may potentially have a role in the development of vascular complications $(2,3,5)$. Activated platelets respond to activated leukocytes and endothelial cells via adhesion molecules linking inflammation and thrombosis (4). Platelets of recent-onset Type 1 diabetic patients have been shown to be activated independently of metabolic control (5).

Platelet volume is a marker of platelet activation and function and is measured using the MPV (10). MPV values can be an effective marker for blood glucose (10-12). MPV values were found to be higher. However, after the blood glucose was reduced, there was a significant decrease in these MPV values $(8,10)$. MPV values have been found to be higher in diabetic patients when compared with normal controls (11). Patients with retinopathy and microalbuminuria had higher MPV values than patients without diabetic complications (9). In previous studies, MPV was observed to be higher in nonpregnant diabetics when compared with the normal population (8-12). Furthermore, in patients with impaired fasting glucose, which is thought to be indicative of prediabetes, a high MPV has been noted (12). In comparison to normal sized platelets, trombocytes with high MPV values are more reactive $(9,10)$. This situation may lead to vasoconstriction and vein occlusion and a decrease in the concentration of prostacylin, resulting in vasoconstriction at the vascular vein level $(2,9)$. It has been argued that an increase in the MPV sets the stage for micro- and macrovascular complications in diabetic patients (9-12).

Increased MPV values have also been reported in various cardiovascular diseases (7-9). MPV values can be an effective marker of blood glucose levels (11-12). Some studies have found that increased aggregation and multiplication functions occur in diabetic patients' megakaryocyte stem cells $(7,8)$. The glycoprotein IB molecule, a marker of megakaryocyte stem cells, is found more frequently in the cell membrane of platelets with high MPV values in diabetic patients (10). Other studies have argued that the number of peripheral platelets may depend on variables such as the platelet production rate and the mean platelet survival (9-11).

In our study, we found that HbAlc levels were increased in GD. This finding was expected. The identification of a larger MPV in GD patients suggests that the MPV may be used as a marker for follow-up of diabetic patients. Its potential needs to be confirmed in further prospective, randomized, controlled studies. Recently, Bozkurt et al. (10) claimed that GD patients had higher MPV values than normal control subjects and that patients with high MPV values had low platelet counts. It has been reported that platelet survival is shorter in diabetic patients $(9,12)$. This may be explained by variables such as platelet production and mean platelet survival. The platelet distribution width displays a good correlation with the MPV. We did not detect a significant difference between the platelet distribution width values between the two groups.

Gestational DM is a systemic disease that affects both the mother and fetus $(10,11)$. These patients are more likely to develop Type 2 DM; hence, they must be monitored closely. As an increased MPV may reflect increased platelet activation, further studies on platelet parameters and functions might be helpful in decreasing the mortality and the morbidity associated with GD.

We are aware of the limitations of this study due to the retrospective design and limited number of study participants, which may fail to demonstrate small differences between the groups. Gestational DM may not always constitute a good model for extrapolation of results to Type 2 diabetes. However, we suggest that modifications in glycemia undetectable by standard clinical laboratory methods can be reflected via alterations in platelet features. We also compared the influences of short-term (gestational) diabetes on platelet parameters of $\mathrm{CBC}$

DM is associated with serious potential systemic and metabolic risks during pregnancy. Diabetic pregnants need to be closely observed during their antenatal checkups. Close observation is essential to prevent complications of diabetic illnesses associated with hyperglycemia, which has a negative influence on all maternal systems and on fetal homeostasis. Further research may indicate higher MPV values in pregnants with poor diabetic control. As studies related to platelet functions in diabetic pregnants increase, we strongly believe that improvements will occur in prenatal and postnatal observation and treatment, which will subsequently result in a decrease in fetomaternal complications.

In conclusion, the present work shows that measurement of the MPV and other platelet-related parameters is a simple procedure, available in most hospital laboratories. These parameters may significantly aid the identification of diabetic pregnants at risk for vascular complications. The role of changes in these parameters in the hemostatic system during diabetic pregnancy and the possible clinical relevance concerning the risk for thrombosis call for further studies.

\section{Conflict of interest}

No conflict of interest was declared by the authors.

\section{References}

1. Pöyhönen-Alho M, Joutsi-Korhonen L, Lassila R, Kaaja R. Alterations of sympathetic nervous system, coagulation and platelet function in gestational diabetes. Blood Coagul Fibrinolysis 2012; 23:508-13. [CrossRef]

2. Stein PD, Goldman J, Matta F, Yaekoub AY. Diabetes mellitus and risk of venous thromboembolism. Am J Med Sci 2009; 337: 259-64. [CrossRef]

3. Farhan S, Winzer C, Tura A, Quehenberger P, Bieglmaier C, Wagner OF, et al. Fibrinolytic dysfunction in insulin-resistant women with previous gestational diabetes. Eur J Clin Invest 2006; 36: 345-52. [CrossRef]

4. Strauss T, Maayan-Metzger A, Simchen MJ, Morag I, Shenkmean B, Kuint J, et al. Impaired platelet function in neonates born to mothers with diabetes or hypertension during pregnancy. Klin Padiatr 2010; 222: 154-7. [CrossRef]

5. Vignini A, Moroni C, Nanetti L, Raffaelli F, Cester A, Gabrielli O, et al. Alterations of platelet biochemical and functional properties in newly diagnosed type 1 diabetes: a role in cardiovascular risk? Diabetes Metab Res Rev 2011; 27: 277-85. [CrossRef] 
Sak et al.

6. Mazzanti L, Nanetti L, Vignini A, Rabini RA, Grechi G, Cester N, et al. Gestational diabetes affects platelet behaviour through modified oxidative radical metabolism. Diabet Med 2004; 21: 68-72. [CrossRef]

7. Barden A, Singh R, Walters BN, Ritchie J, Roberman B, Beilin LJ. Factors predisposing to pre-eclampsia in women with gestational diabetes. J Hypertens 2004; 22: 2371-8. [CrossRef]

8. Erikçi AA, Muhçu M, Dündar O, Oztürk A. Could mean platelet volume be a predictive marker for gestational diabetes mellitus? Hematology 2008; 13: 46-8. [CrossRef]

9. Dundar O, Yoruk P, Tutuncu L, Erikci AA, Muhcu M, Ergur AR, et al. Longitudinal study of platelet size changes in gestation and pre- dictive power of elevated MPV in development of pre-eclampsia. Prenat Diagn 2008; 28: 1052-6. [CrossRef]

10. Bozkurt N, Yilmaz E, Biri A, Taner Z, Himmetoğlu O. The mean platelet volume in gestational diabetes. $\mathrm{J}$ Thromb Thrombolysis 2006; 22: 51-4. [CrossRef]

11. Hekimsoy Z, Payzin B, Ornek T, Kandoğan G. Mean platelet volume in Type 2 diabetic patients. J Diabetes Complications 2004; 18: 173-6. [CrossRef]

12. Coban E, Bostan F, Ozdogan M. The mean platelet volume in subjects with impaired fasting glucose. Platelets 2006; 17: 67-9. Erratum in: Platelets 2006; 17: 350. [CrossRef] 